\title{
Carta de tomar
}

\author{
Luís Antônio Jorge
}

Figura 1: Janela da Sala do Capítulo, no Convento de Cristo, Tomar (Portugal), em estilo manuelino

Foto: Luís Antônio Jorge
Na última semana de julho de 2008, por ocasião do VI Seminário Internacional de Arquitectura, promovido pela Faculdade de Arquitectura da Universidade Técnica de Lisboa, cujo tema foi "Arquitectura e cosmologia: do retorno da diáspora às arquitecturas em equilíbrio - Investigação em arquitectura, urbanismo e design", foi proposto, elaborado e lançado um manifesto denominado Carta de Tomar, com o objetivo de iniciar um processo de constituição de uma Associação de Escolas de Arquitetura e Urbanismo dos Países de Língua Portuguesa. São signatários dessa Carta os professores doutores: Angélica Benatti Alvim (FAU-Mackenzie), Antônio Carpintero (FAUUnB), Conceição Trigueiros (FA-UTL-Portugal), Jorge Cruz Pinto (FA-UTLPortugal), Luís Antônio Jorge (FAUUSP), Luís Conceição (FAUGA-ULHTPortugal), Manuel C. Teixeira (FA-UTL-Portugal), Maria Amélia D. F. Azevedo Leite (FAU-PUCC), Rodrigo C. Queiroz (FAUUSP) e Teresa Fonseca (FAUPPortugal). Essa reunião foi sugerida e estimulada pela conferência apresentada (por meio de gravação em DVD) pelo Prof. Dr. Sylvio B. Sawaya, no âmbito do referido seminário.

0 documento redigido nessa ocasião, pelos professores presentes, chegou à seguinte proposta:

\section{Contexto}

"A língua portuguesa é, hoje, o elo de uma vasta comunidade cultural, de mais de 250 milhões de falantes, que une países e regiões na Europa, nas Américas, na África, no Índico e no Extremo Oriente. Cada uma das realidades que compõem esta comunidade tem de ser entendida em suas raízes européias, africanas, americanas, índicas e orientais.

Essa comunidade cultural, desenvolvendo-se e a enriquecer ao longo de séculos, em múltiplos processos de troca e simbiose, tem como uma de suas expressões materiais mais visíveis um vasto patrimônio urbano e arquitetônico que importa conhecer, preservar, divulgar e manter como referência de nossas ações presentes. Mesmo em situações em que essa cultura comum não sobreviveu

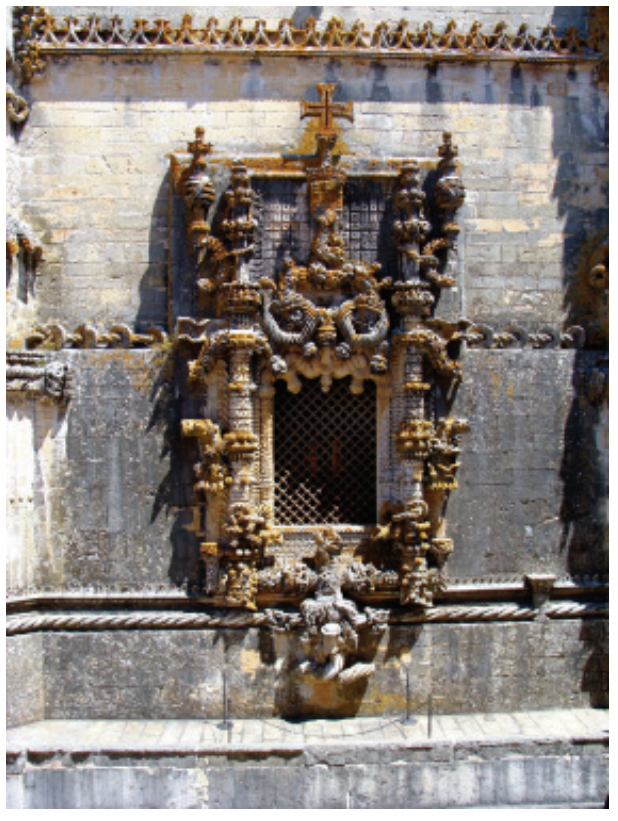


na língua, ela permanece na arquitetura, no urbanismo, nos modos de fazer e construir que resultaram desse encontro de culturas, e de que são testemunhos.

As escolas de arquitetura reunidas em Lisboa, em julho de 2008, tomaram a iniciativa de promover a criação da Associação dos Países de Língua Portuguesa, cujo objetivo é desenvolver ações nos domínios da arquitetura e do urbanismo que visem ao estudo e à preservação desse legado cultural e a consideração desse patrimônio como referência fundamental para a arquitetura e o urbanismo contemporâneos nesses países.

\section{Objetivos}

Promover a cooperação entre escolas de arquitetura nos domínios da arquitetura e do urbanismo com países e regiões de língua portuguesa na América do Sul, África e Ásia e outros países onde existem marcas da cultura lusófona.

Desenvolver essa cooperação nas vertentes do ensino, graduado e pósgraduado, da investigação pura e aplicada, da cooperação técnica e da prestação de serviços, nomeadamente para atender a carências urbanas que convocam a responsabilidade social da arquitetura, envolvendo escolas de arquitetura, centros de investigação, profissionais e investigadores.

Desenvolver ações de sensibilização e formação sobre a cultura urbana e arquitetônica lusófona, a realizar-se nos diferentes países, em escolas de diferentes graus de ensino e junto do público em geral.

Promover publicações, filmes, vídeos, conteúdos em formato digital e outros, sobre a arquitetura e o urbanismo do mundo da língua portuguesa, para apoio de ações de formação, divulgação e sensibilização.

\section{Ações}

As escolas de arquitetura (acima citadas), reunidas em Lisboa, em julho de 2008, decidiram constituir a Comissão Instaladora da Associação de Escolas de Arquitetura dos Países de Língua Portuguesa, com os objetivos de: promover ações de divulgação dessa iniciativa em escolas de arquitetura que não estiveram presentes e elaborar a proposta de estatutos dessa associação, a ser apresentada em reunião no último trimestre de 2008, para sua assinatura formal."

O Manifesto que acompanha a apresentação de intenções acima deve seu nome à programação do referido seminário, que contemplou um dia de trabalhos no Convento de Cristo na cidade de Tomar, lugar emblemático na história da formação de Portugal. Abaixo, a transcrição desse documento:

"A minha língua é a minha pátria. Eis o mote do encontro entre escolas de arquitetura lusófonas. Por isso temos de aprofundar nosso relacionamento no sentido de promover o ensino da arquitetura no vasto espaço da lusofonia.

A língua não é apenas um elemento comum. Construímos Pela língua discursos e estes são a expressão de nosso pensamento. A partilha da língua é sempre proximidade de pensamento. A língua não é apenas um instrumento de cultura, mas a expressão mais acabada. Porque nos entendemos, temos um patrimônio comum que fundamenta nossas culturas. Partilhar a mesma língua é explicar o cosmo da mesma maneira, e não faz sentido, dentro desse espaço lingüístico, não cultivarmos, aprofundando-a, a nossa cultura. 
Ora, é sabido que ao lado da produção arquitetônica, justificando-a, legitimando-a e escrevendo-a, há um discurso que é a expressão do pensamento dos arquitetos. $O$ fato de estarmos geograficamente distantes não obsta, porém, a que, em pensamento, estejamos muito próximos. E, no pensamento, gera-se a arquitetura. É, aliás, essa diversidade no território que tem possibilitado um enriquecimento mútuo. A poesia, a literatura, a música, a pintura são a prova viva disso. E se assim é, não há razão para que este encontro não deixe de ser encorajado por iniciativas institucionais ao mais alto nível.

Queremos criar uma associação das escolas de arquitetura do universo lusófono de todo o mundo. Essa será uma maneira de acertarmos o passo nesse percurso que já foi comum.

Esta reunião deverá constituir o primeiro passo de um projeto mais ambicioso em termos culturais, que terá como objetivo projetar no mundo as obras, os saberes e os métodos da sensibilidade lusófona em suas diferentes manifestações arquitetônicas e urbanísticas. Tomar, com o seu Convento de Cristo, acolhe, em julho de 2008, os representantes das escolas como promotores originais dessa e, participantes do $6^{\circ}$. Seminário Internacional de Arquitetura, organizado pela Faculdade de Arquitectura da Universidade Técnica de Lisboa, para, conjuntamente, refletirem sobre o passado, o presente e o futuro da arquitetura, enquanto profissão, enquanto arte, enquanto prática do espaço, enquanto suporte da vida, enquanto modo de sentir e de enquadrar a vida.

Este primeiro encontro lançará as bases para o estabelecimento de um programa conjunto, consagrando aqueles objetivos que se pretende envolver a todos os países lusófonos.

O Convento de Cristo acolhe, na perfeição, o simbolismo desta ação inaugural."

A publicação desse informe na revista Pós da FAUUSP visa à divulgação dessa iniciativa e, simultaneamente, à formulação de um convite a todos que queiram se integrar a ela, participando desse esforço inicial de intercâmbio cultural, acadêmico e profissional.

\section{Luís Antônio Jorge}

Professor do Departamento de Projeto e professor-orientador do curso de pósgraduação da FAUUSP. 